\title{
Türkiye'deki COVID-19 yayılımının SIR temelli modellenmesinde RSS yöntemi ile parametre kestirimi
}

\author{
Unknown SIR parameters' estimation of COVID-19 spread in Turkey by using RSS method
}

\author{
Nurbanu GÜZEY ${ }^{* 1, a}$ \\ ${ }^{1}$ Erzurum Teknik Üniversitesi, Mühendislik ve Mimarlık Fakültesi, Elektrik-Elektronik Mühendisliği Bölümü, 25050 Erzurum
}

• Geliş tarihi / Received: 24.06.2020 • • Düzeltilerek geliş tarihi / Received in revised form: 29.04.2021 • Kabul tarihi / Accepted: 13.06 .2021

Öz

Global COVID-19 salgınını sona erdirmek, sosyal izolasyon, çok sayıda test ve insanların birbirleriyle olan iletișimini izleme gibi ülke çapında geçerli birden çok stratejinin uygulanmasını gerektirir. Bu kapsamda, dünya üzerinde birçok ülke kendine özgü kısıtlamalar getirdi. Kısıtlamalar getirilirken hastane kapasiteleri, sosyal hayat ve ekonomi gibi birçok parametre dikkate alındı. İtalya, Brezilya ve hatta Amerika Birleşik Devletleri gibi bazı ülkeler, salgının seyrini kestiremeyip daha sıkı önlemler almayınca salgın binlerce can kaybına sebep oldu ve halen de olmaktadır. Bu çalışmada Türkiye'de görülen vaka sayılarıyla ve alınan tedbirler doğrultusunda salgının başlangıcından itibaren 91 gün boyunca nasıl bir seyir izlediğinin modellenmesi yapılmıştır. Modelleme yapılırken, epidemiyolojide yaygın olarak kullanılan SIR (Susceptable-Infected-Recovered, Korunmasız-Enfekte-Bulaşıcı Olmayan) modeli kullanılmıştır. Modellemede, parametre kestirimi için RSS (Residual Sum of Squares, Kalan Kareler) yönteminden faydalanılmıştır. Okulların tatil edilmesi, sokağa çıkma yasakları ve alınan tedbirlerin kısmen kaldırılması gibi önemli tarih aralıkları ayrı ayrı dikkate alınarak yapılan parametre kestirimleri ile T.C. Sağlık Bakanlığınca verilen salgın verilerine uygun bir modelleme yapılmıştır. Ayrıca, salgın başlangıcında önlem alınmasaydı ya da en son alınan tedbirler devam ettirilirse salgının seyrinin nasıl gerçekleşebileceğini öngören sonuçlar verilmiştir. Bu model, yetkililere salgını yönetmek için bir ön değerlendirme imkânı sunmaktadır.

Anahtar kelimeler: COVID-19, RSS, SIR yayılım modeli

\begin{abstract}
Ending the global COVID-19 outbreak requires multiple country-wide strategies, such as social isolation, multiple tests, and monitoring people's interactions with each other. Many countries in the world have brought their own restrictions. Many parameters such as hospital capacities, social life and economy were taken into consideration while introducing the restrictions. Some countries, such as Italy, Brazil, and even the United States, have failed to predict the course of the outbreak and did not take more stringent measures, therefore; the outbreak has caused thousands of lives and is still happening. In this study, by considering the number of COVID-19 cases and the measures taken by the government, a model was developed to track the course of the epidemic for 91 days. For modeling, the SIR (Susceptible-InfectedRecovered) model, which is widely used in epidemiology was used. To estimate the parameters in the SIR model, RSS (Residual Sum of Squares) method was utilized. By taking into account the important time intervals, such as closure of the schools, country wide lockdowns and bending the restrictions, the model parameters were estimated for these intervals using the epidemic data given by the Ministry of Health. In addition, simulation results are provided to predict how the course of the epidemic would take place if precautions were not taken at the beginning of the outbreak or if the most recent measures were continued. This model offers authorities a preliminary assessment opportunity to manage the outbreak.
\end{abstract}

Keywords: COVID-19, RSS, SIR spread model

\footnotetext{
${ }^{{ }^{*} a}$ Nurbanu GÜZEY, nurbanu.guzey@erzurum.edu.tr, Tel: (0552) 23825 23, orcid.org/0000-0002-6587-2489
} 


\section{Giriş}

Ciddi ve potansiyel olarak ölümcül bir solunum sendromuna neden olan yeni tip Coronavirus (SARS-CoV-2), yani COVID-19, Aralık 2019'da, Çin'in Hubei Eyaleti, Wuhan şehrinde ortaya çıtıtı. O zamandan sonra bütün dünyayı etkileyen virüs, Dünya Sağlık Örgütü (WHO) tarafından 11 Mart 2020 tarihinde küresel bir pandemi olarak ilan edildi (WHO, 2020; Wu vd., 2020; Kraemer vd., 2020). Dünya Sağlık Örgütü kendi resmi web sitesinde ülkelere pandemi ile nasıl mücadele edebileceklerini anlatan önerilerde bulunmuştur (WHO, 2020). Bu tarihten sonra bulaşıcı hastalık bütün dünya için ciddi bir sağllk tehdidi olmuştur. İtalya, İspanya ve ABD gibi birçok ülke salgından ciddi şekilde etkilendi. Henüz virüsü durduracak ilaç veya aşı bulunamadığından, şimdilik sosyal mesafe, karantina ve maske takmak gibi önlemler salgının yayılmasinda ve kontrol altına alınmasında kullanılan stratejilerdir.

Bu bağlamda, salgının yayılımı, ölüm ve iyileşme sayıları gibi parametrelerin kestirimi için matematiksel modellere ihtiyaç vardır. Farklı ülkeler salgının yayılmasını önlemek için farklı ve önemli tedbirler aldılar, ancak nüfus yoğunluğu, virüsün bilinmeyen farklı etkileri, bulaşma mekanizması ve henüz bir ilaç bulunamaması özellikle Hindistan gibi nüfus yoğunluğunun fazla olduğu ülkelerde bu denli bulaşıcı ve öldürücü bir hastalıkla baş etmeyi çok zorlaştırmaktadır (Dandekar vd., 2020; Ranjan vd., 2020; Pulla vd., 2020).

$\mathrm{Bu}$ çalışmanın amacı, COVID-19 pandemisinin yayılım modelinin alınan önlemler doğrultusunda nasıl davrandığını belirleyip, daha sonra alınacak önlemlerin pandeminin seyrini nasıl devam ettireceğinin kestirimini yapmaktır. Epidemiyolojik literatüre bakılırsa, salgın hastalıkların modellenmesi ilk olarak Bernoulli tarafından 1760 yıllarında yapılmıştır. Daha sonra, bu hastalıkların bulaşmasını ve kontrolünü etkileyen yayılma mekanizmalarını ortaya çıkarmak amacıyla bulaşıcı hastalıkları incelemek için çeşitli matematiksel modeller kullanılmıştır (Brauer vd., 2001). Kermack ve McKedrick (Kermack vd., 1927) tarafindan 1927 y1lında Mumbai'deki veba salgınını modellemek için geliştirilen SIR modeli, epidemik yayılımın modellenmesinde kullanılan en yaygin metotlardan biridir. Epidemik analizde, bölmeli modelleme grubuna (Brauer, 2017) giren SIR modelinde toplum üç gruba ayrılır. Gruplar arası geçişler ve salgının seyri, bu gruplardaki değişimi belirten adi diferansiyel denklemlerle ifade edilir. Denklem modelindeki katsayılar ise toplum koşullarına bağlı olarak değişen bulaşıcılık oranı ve iyileşme oranlarına bağlıdır.

SIR modeli daha da geliştirilerek doğum ve ölüm oranları da sisteme katılmıştır (Kermack vd.,1932). Sonraki çalışmalarda SIR modelini daha realistik yapmak için farklı bölmeler eklenmiştir; korunmasız grubunu virüse maruz kalmış ancak semptom göstermeyenlerden ayırmak için SEIR (Chowell vd., 2020) modeli, karantinaya alınmış kişi sayısını hesaba katan SEIQR (Vyasarayani vd.,2020) modeli ve doğuştan bağışıklığa sahip olanların varsayıldığı MSEIR (Almeida vd.,2019) modeli gibi.

Nesteruk, (2020), Güney Kore'deki COVID-19 salgınını SIR modeline uygun olarak modellenmiştir ancak bu çalışmada Güney Kore'deki farklı zamanlardaki kisıtlamalar dikkate alınmamıştır. Eroglu (2020)'de ise, SIR modeli kullanılarak bir salgın modelleme ve destek sistemi simülatörü geliştirilmiştir, lakin SIR modelinde kullanılan diferansiyel denklemler çözülürken bulaşıcılık ve iyileşme oranlarının bilindiği varsayılmıştır.

Ayrıca (Alenazi vd.,2020; Ndiaye vd.,2020) gibi çalışmalarında ise salgının modellenmesinde makine öğrenmesi yöntemi kullanılmıştır. Fakat bu gibi yapay zekâ tekniklerinin doğru sonuç verebilmesi için çok miktarda örnek gerekmektedir.

Bu çalışmada, Türkiye'de salgının başlangıcından itibaren 91 gün boyunca Sağlık Bakanlığınca sunulan verilerden (T.C. Sağlık Bakanlığı, 2020), enfekte olan hasta sayısı, ölen ve iyileşen kişi sayıları ile SIR modeli kullanılarak salgının nasıl seyrettiğinin modeli çıkarılmıştır. Ancak bakanlık tarafinca sağlanan verilerde hasta veya iyileşenlerin yaş oranları, karantinaya alınan kişi sayıs1 ya da virüse maruz kalıp belirti göstermeyen kişi sayıları belirtilmediği için ve hızlı bir sonuç alınabilmesi bakımından en basit bölmeli model olan SIR modeli tercih edilmiştir. Model çıkarılırken salgın süresi boyunca alınan, okulların tatil edilmesi, sokağa çıkma yasaklarının başlaması gibi tedbirler de göz önünde bulundurularak salgının farklı dönemleri (Wikipedia, 2020) için, farklı bulaşıcılık oranı ve iyileşme oranları bulunmuştur. Ayrıca, eğer salgın başlangıcında önlem alınmasaydı ya da en son alınan tedbirler devam ettirilirse salgının nasıl bir seyir izleyebileceği gösterilmiştir. Böylece, hangi tedbirlerin salgının seyrini ne derece etkilediği model sayesinde elde edilerek yetkili makamlara 
alınabilecek tedbirler için bir ön değerlendirme imkanı sunacaktır.

İlaveten, bütün dünyayı derinden etkileyen bu salgının, yetkili kurumlarca sağlanacak detaylı verilerin kullanılarak daha ayrıntılı bir modelinin çıkarılması da, daha sonra gerçekleşebilecek böyle bir salgın durumunda daha doğru öngörüler sunacaktır. Bir sonraki bölümde, modellemede kullanılan SIR modeli ayrıntılı olarak anlatılmıştır.

\section{Materyal ve yöntem}

$\mathrm{Bu}$ bölümde, salgının modellenmesi ve alınacak tedbirler doğrultusunda yayılımının nasıl olacağını kestirmek için kullanılacak olan SIR modeli anlatılmıştır. Yöntem toplumu üç grupta inceler;

- S (susceptable, korunmasız): sağlıklı ancak hastalığa korunmasız olanlar (yani virüs bulaşma riski olanlar). Pandeminin başlangıcında, S virüse bağışıklık olmadı̆̆1 için tüm toplumdur.

- I (infected, virüs bulaşmış bireyler): dolayısıyla, başka insanlara da bulaştırma riski olan bireyler.

- $\mathrm{R}$ (recovered, bulaşıcılığı olmayan): virüs bulaşmış, sonrasında iyileşmiş ya da ölmüş kişiler. $\mathrm{Bu}$ bireyler artık bulaştırıcı değillerdir.

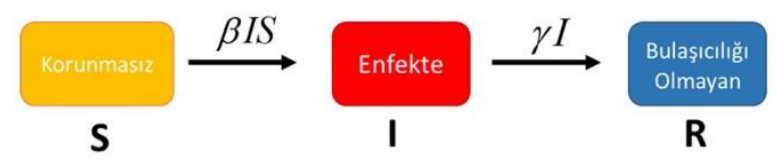

Şekil 1. SIR Modeli (Kermack, 1927).

$\mathrm{Bu}$ gruplardaki kişi sayısı, virüs popülasyon içerisinde yayıldıkça zamanla değişir; virüs bireylere bulaştıkça $S$ azalır I artar. İnsanlar iyileştikçe veya öldükçe, enfekte grup I'dan sadece artık bulaşıcı olmayan $\mathrm{R}$ grubuna giderler. İyileşmiş kişilerin bağışıklık kazanıp tekrar enfekte olmayacakları varsayımı yapılmıştır. Ayrıca modelde toplam nüfus sabit ve homojen kabul edilmiştir. Başka hastalıklardan kaynaklanan ölümler ihmal edilmiştir. Şekil 1'de gösterildiği gibi modelde geçişler tek yönlü ve sağ tarafadır. Yöntem, gruplar arasındaki geçişleri adi diferansiyel denklemler (ODE) kullanarak belirler. Bir salgının başlangıç koşulları ve gelişimi aşağıdaki gibidir:
1) Hastalık salgını başlamadan önce $S$, hiç kimsenin bağışıklığ1 olmadığ 1 için tüm nüfusa eşittir, I ve R grubundaki kişi sayısı başka hastalıklar dikkate alınmadığ 1 için 0'dır.

2) Salgının başlangıcında sadece 1 bireyin enfekte olduğu varsayılır ve ilk birey enfekte olur olmaz, S, 1 azalir ve I, 1 artar.

3) $\mathrm{Bu}$ ilk bulaşıcı birey, korunmasız olan diğer kişilere (iyileşmeden veya ölmeden önce) hastalığı bulaştırır.

4) Dinamik, yakın zamanda virüs kapmış bireyler, diğer korunmasız insanları enfekte ederek salgın devam eder.

5) Kişiler hastalıktan iyileştikçe veya öldükçe R grubundaki kişi sayısı da zamanla artar.

Salgının dinamiklerini modellerken, her bir gruptaki değişim oranlarını tanımlamak için üç farklı denkleme ihtiyaç vardır:

$$
\begin{aligned}
\dot{S}(t) & =-\frac{\beta I(t) S(t)}{N} \\
\dot{I}(t) & =\frac{\beta I(t) S(t)}{N}-\gamma I(t) \\
\dot{R}(t) & =\gamma I(t)
\end{aligned}
$$

Burada $\dot{S}(t)$ virüse karşı korunmasız olan $\mathrm{S}$ grubundaki kişi sayısının zamana göre değişimini, $\dot{I}(t)$ enfekte olmuş I grubundaki kişi sayısının zamana göre değişimini ve $\dot{R}(t)$ artık bulaşıcılığ 1 olmayan R grubundaki kişi sayısının zamana göre değişimini göstermektedir. Ayrıca $\beta, \mathrm{S}$ ve I arasındaki geçişi kontrol eden enfeksiyon oranını, $\gamma$, I ve R arasındaki geçişi kontrol eden çıkarma veya iyileşme oranını temsil etmektedir. $\mathrm{N}$ bütün gruplardaki kişilerin toplamıdır.

Denklem (1), S grubundaki korunmasız kişi sayısının, yeni enfekte olan kişi sayısı oranında düştüğünü belirtir. Denklem (2)'de, I grubundaki kişi sayısı, yeni enfekte olmuş kişilerle birlikte artmakta ancak iyileşen ya da ölen kişilerle birlikte azalmaktadır. Denklem (3) ise, bulaşıcılığ olmayan $\mathrm{R}$ grubunun enfekte olduktan sonra iyileşen veya ölen bireylerin sayısı ile arttığını belirtmektedir. Zaman verisi sonsuza yaklaştığında $\lim _{t \rightarrow \infty} S(t)=0, \lim _{t \rightarrow \infty} R(t)=N$ olur. SIR metodunda verilen birinci dereceden adi diferansiyel denklemleri ayrık zamanda çözmek için Euler yöntemi kullanılabilir. Böylece denklemler;

$S_{n+1}=S_{n}-\frac{\beta S_{n} I_{n} \Delta t}{N}$ 


$$
\begin{aligned}
& I_{n+1}=I_{n}\left(1+\left(\frac{\beta S_{n}}{N}-\gamma\right) \Delta t\right) \\
& R_{n+1}=R_{n}+\gamma I_{n} \Delta t
\end{aligned}
$$

halini alır. Burada $\Delta t=t_{n+1}-t_{n}$ zamanda küçük bir değişimi ifade eder, bu çalışmada değişim, $\Delta t, 1$ gün olarak kabul edilmiştir. $S_{n+1}, I_{n+1}, \mathrm{R}_{n+1}$ korunmasız, enfekte olmuş ve artık bulaşıcılığı olmayan kişi sayısıdır. Ancak bu denklemlerin çözümü için enfeksiyon oranı $\beta$ ve iyileşme oranı $\gamma$ bilinmelidir.

$\mathrm{Bu}$ tarz kestirimlerde, kalan kareler toplamı (RSS) ya da ortalama karekök (RMS) gibi eldeki verilerle modelin arasındaki farkı en aza indiren parametreleri bulan yöntemler kullanılabilir. Aşağıdaki eşitlikte, kalan kareler toplamı (RSS) yöntemi kullanılarak, enfekte olmuş kişi sayıları üzerinden enfeksiyon oranı $\beta$ ve iyileşme oranı $\gamma$ kestirilmiştir.

$$
R S S(\beta, \gamma)=\sum_{n}\left(I_{n}^{d}-I_{n}\right)^{2}
$$

Burada $I_{n}^{d}, n$ anında, sağlık birimlerince verilen enfekte olmuş kişi sayısını, $I_{n}$ ise (7)'de verilen, modelle kestirilen, enfekte olmuş kişi sayısını belirtmektedir. $\beta$ ve $\gamma$ değerlerine belirli aralıkta ve mümkün olduğunca kısa iterasyon aralığında değerler verilerek parametre uzayı taranır ve (7)'yi minimum yapacak $\beta$ ve $\gamma$ değerleri belirlenir. Belirlenen $\beta$ ve $\gamma$ değerleri kullanılarak, ilerleyen zamanlarda, her guruptaki (S, I, R) kişi sayılarının nasıl değişiklik göstereceği kestirilebilir.

Bir sonraki bölümde SIR modeli kullanılarak Türkiye'de salgının 91 gün boyunca nasıl değişim gösterdiği simülasyon sonuçlarıyla verilmiştir.

\section{Bulgular ve tartışma}

$\mathrm{Bu}$ bölümde, önceki bölümde verilen SIR modeli ile Türkiye'deki veriler kullanılarak, belirsiz parametrelerin, $\beta, \gamma$, değerleri belirli aralıklarda tespit edilmiştir. $\mathrm{Bu}$ aralıklar belirlenirken, pandeminin başlangıcından itibaren bazı tarihlerde alınan tedbirler dikkate alınmıştır. O tedbirler şu şekildedir (Wikipedia, 2020);

- 11 Mart, Türkiye'deki ilk COVID-19 vakasıdır (1. gün).

- 16 Mart, okulların kapalı olduğu ve Türk hükümeti tarafindan hafif COVID-19 önlemlerinin ilan edildiği gündür (6. gün).
- 11 Nisan, hafta sonlarındaki sokağa çıkma yasaklarının başladığı gündür (31. gün).

- 23 Nisan, hafta sonları dahil dört günlük sokağa çıkma yasakları gibi daha sık1 tedbirlerin alındığı gündür (43. gün).

- 1 Haziran, hafta sonu sokağa çıkma yasakları, şehirlerarası seyahat yasakları gibi diğer bazı tedbirlerin hükümet tarafından rahatlatıldığı gündür (81. gün).

Bu çalışma 9 Haziran 2020 tarihinde T.C. Sağlık Bakanlığı tarafından sağlanan verilere dayanılarak hazırlanmıştır (T.C. Sağlık Bakanlığı, 2020). Bu tarihe kadar Türkiye'de ilk COVID-19 vakasının görüldügü günden itibaren 91 gün geçmiştir. Yukarıda verilen tarihler, pandemi sürecinin aralıkları olarak kabul edilip, her bir aralık için enfeksiyon oranı, $\beta$ ve iyileşme oranı $\gamma$, RSS yöntemi ile belirlenmiştir. $\beta$ ve $\gamma$ değerleri için parametre uzayı belirlenirken, salgın devam ettiği ve model tek yönlü olduğundan $\beta>0$ ve $\gamma>0$ dır.

MATLAB programı kullanılarak yapılan parametre kestirimlerinde iki aşamalı bir yaklaşım kullanılmıştır. Birinci aşamada, parametre uzayı, (0-100) ve adım aralığ 1 , (0.5), geniş tutulmuştur. RSS yöntemiyle, $200 \times 200=40000$ deneme sonunda, en küçük RSS değerini veren $\beta, \gamma$ değerleri tespit edilmiştir. İkinci aşamada ise, birinci aşamada tespit edilen $\beta, \gamma$ değerlerinin civarında, adım aralığı 0.01 e indirilerek, tekrar en küçük RSS değerini veren $\beta, \gamma$ değerleri tespit edilmiştir. Her bir aralık için belirlenen değerler Tablo 1'de gösterilmiştir.

Tablo 1. Farklı dönemlerde alınan tedbirler doğrultusunda bulunan, $\beta$ ve $\gamma$ değerleri

\begin{tabular}{ccc}
\hline Tarih Aralı̆̆ı & $\boldsymbol{\beta}$ & $\boldsymbol{\gamma}$ \\
\hline 11 Mart-16 Mart & 1.23 & 0.20 \\
16 Mart- 11 Nisan & 0.44 & 0.55 \\
11 Nisan- 23 Nisan & 0.49 & 0.50 \\
23 Nisan- 1 Haziran & 0.47 & 0.51 \\
1 Haziran sonras1 & 0.49 & 0.49 \\
\hline
\end{tabular}

Bulunan enfeksiyon oranı $\beta$, ve iyileşme oranı $\gamma$ değerlerine göre oluşturulan model kullanılarak henüz enfekte olmamış, korunmasız kişi sayısı $\mathrm{S}$, enfekte olmuş kişi sayısı I, ve artık bulaşıcılığı olmayan kişi sayısı R, sırasıyla Şekil 2, Şekil 3 ve Şekil 4'te verilmiştir. 


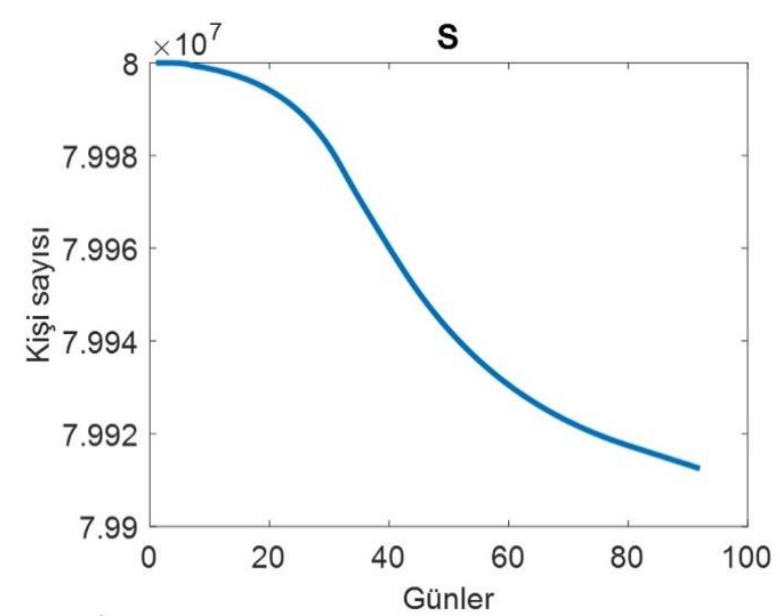

Şekil 2. Bulunan modele göre henüz virüs bulaşmamış kişi sayısı. (Değerler günlük verilerdir)

Şekil 2'de henüz enfekte olmamış kişi sayısı modelden ve RSS yöntemi kullanılarak bulunan enfekte olan ve artık bulaşıcılığ sayısının toplam popülasyondan çıkarılmasıyla bulunmuştur.

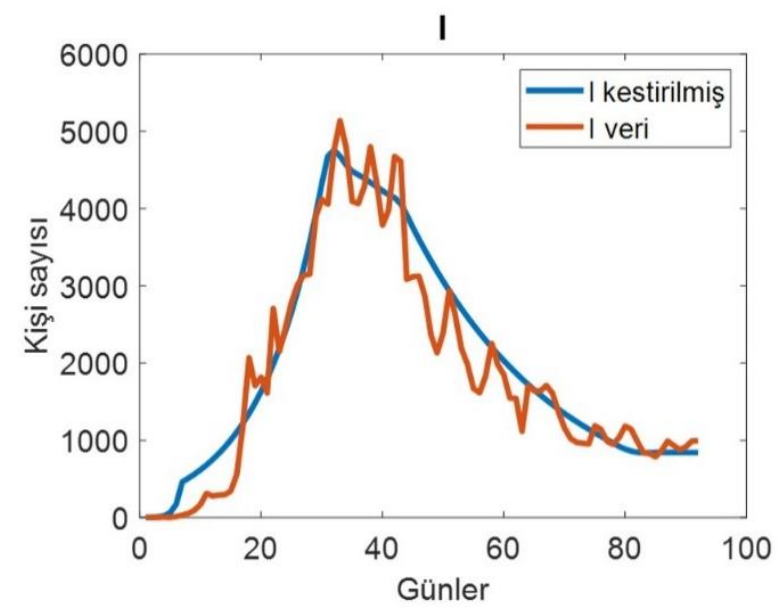

Şekil 3. Gerçek verilere ve modele göre efekte olmuş kişi sayısı.

Bu çalışmada $\beta$ ve $\gamma$ değerleri, Sağlık Bakanlığınca paylaşılan enfekte olmuş kişi sayısı ile modelden kestirilen kişi sayısı arasındaki farkı minimum yapacak şekilde hesaplanmıştır. Hesaplanan $\beta$ ve $\gamma$ değerleri kullanılarak kestirilen günlük enfekte olmuş kişi sayısı ile bakanlık tarafindan paylaşılan kişi sayısının karşılaştırılması Şekil 3'te verilmiştir. Şekilden de görüleceği üzere, model gerçek verilere iyi bir şekilde uymaktadır.

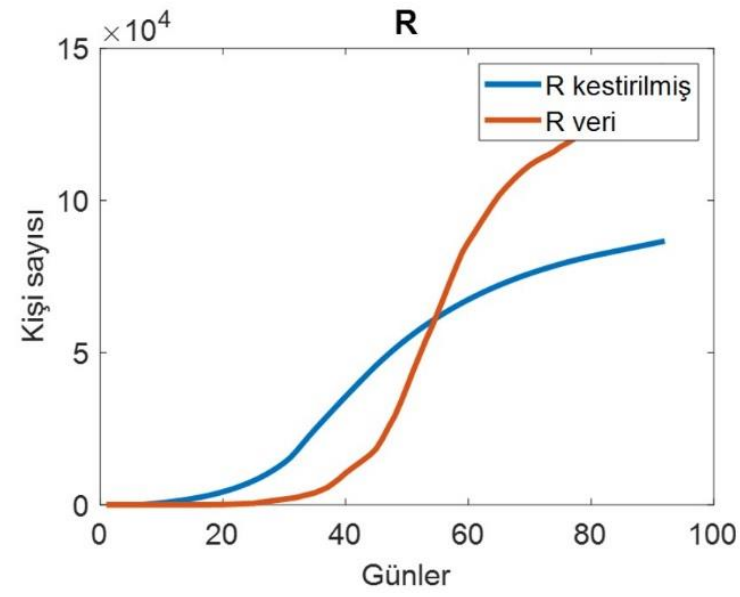

Şekil 4. Gerçek verilere ve modele göre, kümülatif bulaşıcı olmayan kişi sayısı.

Şekil 4'te ise artık bulaşıcılığı olmayan yani iyileşmiş ya da ölmüş kişi sayısının model ve bakanlıkça verilen değerlerinin karşılaştırması verilmiştir. Şekil 4'te belli bir noktadan sonra kestirilen bulaşışı olmayan kişi sayısı verilerden bir sapma göstermiştir. Bu sapmada, $\beta$ ve $\gamma$ oranlarının temas sayısın 1 ve karantina gibi parametreleri dikkate almadan, enfekte olan kişi sayıları baz alınarak kestirilmesinin de etkisi vardır.

Türkiye Cumhuriyeti hükümetince alınan tedbirlerin salgının yayılmasında nasıl bir etki ettiğini göstermek için, tedbirlerin alınmadığı varsayılarak ilk 6 gün için bulunan $\beta=1.23$ ve $\gamma=0.20$ değerleri diğer günler için de kullanılarak yapılan kestirimler Şekil 5-Şekil 7'de gösterilmiştir.

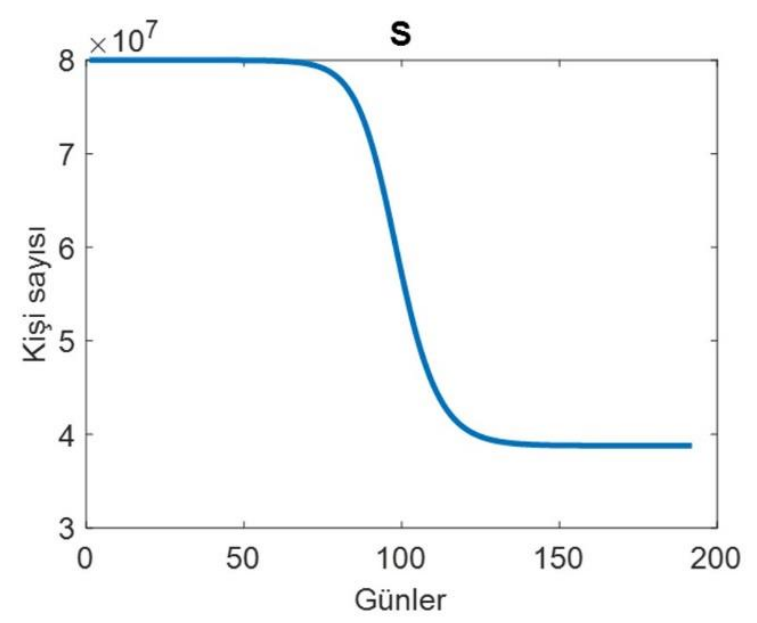

Şekil 5. Eğer salgın için hiç tedbir alınmasaydı virüs bulaşmamış kişi sayısı.

Şekil 5'ten görüleceği üzere, eğer hiçbir önlem alınmasaydı, pandeminin başlamasından itibaren 100. günde popülasyonun yarısı enfekte olmuş 
olacakt1. 100. günden sonra da yeni enfekteler, iyileşmeler ve ölümler devam edeceğinden enfekte olmuş kişi sayısı sabit seviyelerde devam edecekti.

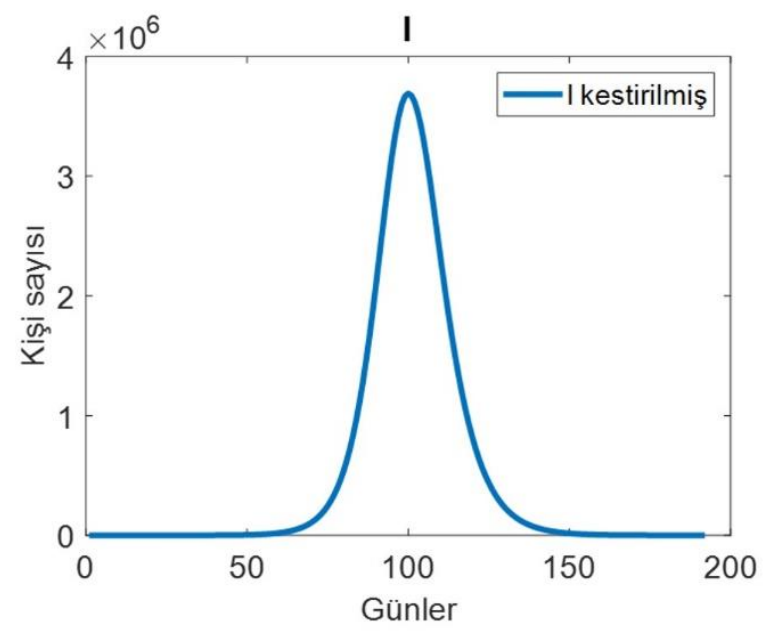

Şekil 6. Eğer salgın için hiç tedbir alınmasaydı, bulunan modele göre enfekte sayısı.

Şekil 6' da görüldüğü gibi salgının başlamasından itibaren herhangi bir önlem alınmasaydı, enfekte olan kişi sayısı belirli bir düzeye kadar (50. güne kadar) yavaşça artacak, 50. günden itibaren çok hızlı bir şekilde artıp 100. günden itibaren hızlı bir düşüşe geçecekti. Düşüşün sebebi, hastaların sağlık durumuna, hastane kapasitelerine bağlı olarak ya iyileşmesi ya da ölmesidir.

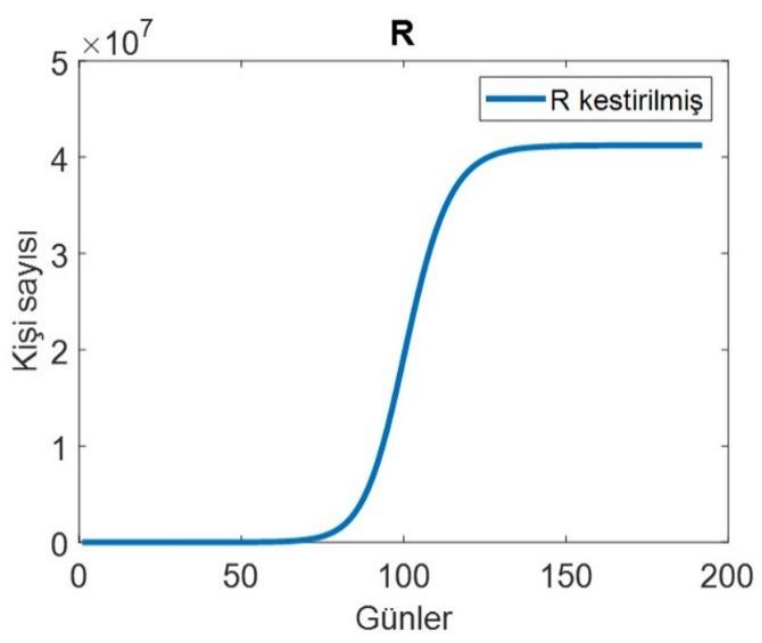

Şekil 7. Eğer salgın için hiç tedbir alınmasaydı, bulunan modele göre artık bulaşıcilığ olmayan kişi sayısı.

Şekil 7'de, salgın için herhangi bir önlem alınmaması durumunda, Şekil 6'da da belirtildiği gibi 100. gün dolaylarında enfekte olan kişi sayısı maksimum değerine ulaştıktan sonra, bulaşıcılığı olmayan kişi sayısı hızlıca artarak 120. günden sonra sabit bir değerde seyredecekti.
1 Haziran tarihinde uygulanan tedbirler ile devam edildiği takdirde, modele göre sonraki günlerde salgının seyrinin Şekil 8-Şekil 9'daki gibi seyredeceği öngörülmektedir.

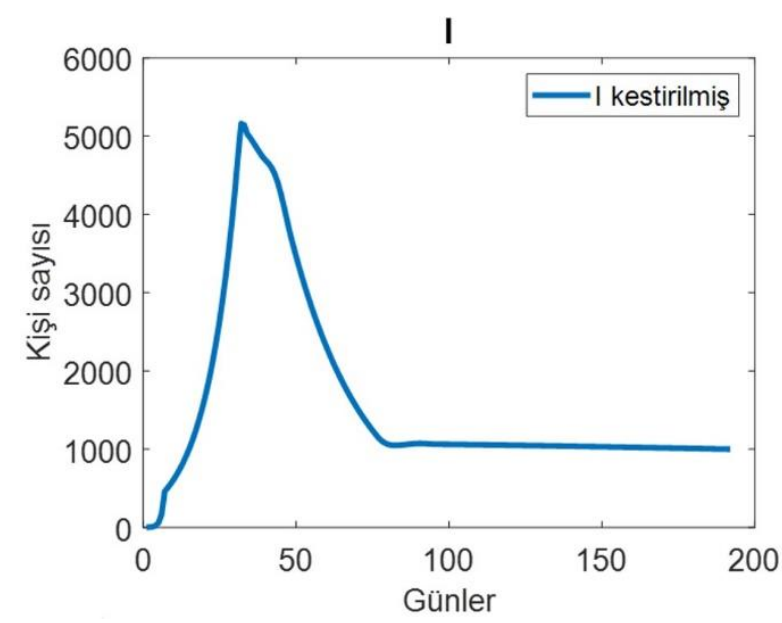

Şekil 8. 1 Haziran 2020 tarihindeki tedbirlerle devam edildiği takdirde enfekte olan kişi sayıs1.

1 Haziran 2020 tarihinden itibaren uygulanan tedbirler devam ederse, günlük enfekte olan kişi sayıs1 91. günden itibaren neredeyse sabit bir şekilde, günlük 1000 kişi dolaylarında devam etmesi Şekil 8'de gösterildiği gibi öngörülmektedir.

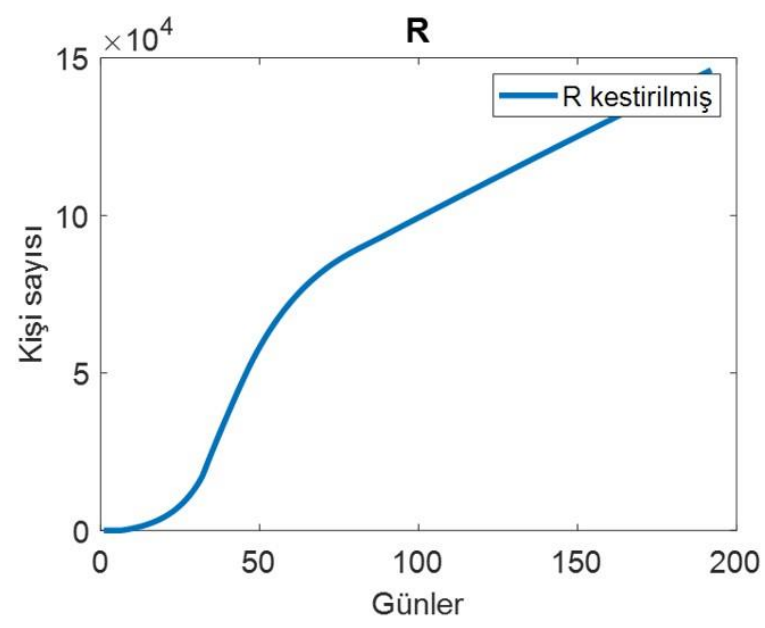

Şekil 9. 1 Haziran 2020 tarihindeki tedbirlerle devam edildiği takdirde bulaşıcıllığı olmayan kişi sayısı.

Şekil 9'da ise, enfekte olan kişi sayısının Şekil 8'de gösterildiği gibi 50. gün dolaylarında maksimum seviyeye ulaşmasından sonra, artık bulaşıcılığı olmayan kişi sayısının lineer bir şekilde artış göstereceği belirtilmiş̧ir. 
Bir sonraki bölümde, bu çalışmanın sonucunda elde edilen kazanımlar ve ilerde yapılması planlanan çalışmalar hakkında bilgi verilmektedir.

\section{Sonuç ve öneriler}

Bu çalışmada, Türkiye'deki COVID-19 yayılımı SIR modeline uydurulmuştur ve modeldeki belirsiz parametreler, dört farklı aralıkta, RSS yöntemi kullanılarak kestirilmiştir. Bu parametreler, belirli aralıklarda sabit olarak kabul edilmiştir. Model dinamiğindeki belirsiz parametrelere belirli aralıkta değerler verilerek elde edilen model çıktılarının, gerçek değerlerle olan farkının RSS değeri hesaplanmış ve en küçük RSS değerini veren parametreler belirlenmiştir.

SIR, pandemi modellemede kullanilan en temel ve basit yöntemlerden biridir. T.C. Sağllk Bakanlığı'ndan alınan verilerin detaylı olmamasından ötürü, günlük kontak sayıları, yaş grupları, temaslılardan hastalık bulaşma oranları gibi parametreler dikkate alınmayarak toplum homojen kabul edilmiştir. Bununla birlikte Türkiye'de pandeminin başlamasından itibaren 3 aylık bir süre zarfinda, yetkililerce alınan tedbirler göz önünde bulundurularak salgının nasıl ilerlediği konusunda hizlı bir öngörü vermesi sebebiyle bu çalışmada tercih edilmiştir.

Daha sonraki çalışmalarda, bakanlıktan detaylı verilerin alınma imkânı olması durumunda, kontak sayısı, karantinaya alınmış kişi sayısı, ölmüş ve iyileşmiş kişilerin ayrı ayrı değerlendirildiği SEIR, SEIQR gibi yöntemlerden faydalanılarak daha detaylı çalışmalar gerçekleştirilebilir. Ayrıca, model parametrelerini belirli aralıklarda sabit tutmak yerine dinamik olarak hesaplanarak daha doğru kestirimler gerçekleştirilebilir.

\section{Kaynaklar}

Alanazi, S.A., Kamruzzaman, M.M., Alruwaili, M., Alshammari, N., Alqahtani, S.A. and Karime, A. (2020). Measuring and preventing COVID-19 using the SIR model and machine learning. Smart Health Care Journal of Healthcare Engineering 8, 1-12. https://doi.org/10.1155/2020/8857346

Almeida R., Brito da Cruz A., Martins N. and Monteiro M. (2019). An epidemiological MSEIR model described by the Caputo fractional derivative. International Journal of Dynamics and Control. International Journal of Dynamics and Control, 7, 776-784. https://doi.org/10.1007/s40435-0180492-1.
Brauer, F. and Castillo-Chavez, C. (2001). Mathematical models in population biology and epidemiology. New York: Springer.

Brauer, F. (2017). Mathematical epidemiology: Past, present, and future. Infectious Disease Modelling, 2, 113-127.

Chowell, G. (2017). Fitting dynamic models to epidemic outbreaks with quantified uncertainty: A primer for parameter uncertainty, identifiability, and forecasts. Infectious Disease Modelling, 2, 379398.

Dandekar, R., and Barbastathis, G. (2020). Quantifying the effect of quarantine control in COVID-19 infectious spread using machine learning. medRxiv. $1-13$. https://doi.org/10.1101/2020.04.03.20052084.

Eroglu, E., Bozkurt, E., Esenpinar, A.A. and Tek, S. (2020). Mathematical analysis of Covid-19 phenomenon. Journal of Engineering Technology and Applied Sciences, 5, 59-64. https://doi.org/10.30931/jetas.739270

Health Organization, Coronavirus disease (COVID-19) outbreak,

https://www.who.int/emergencies/diseases/nove 1- coronavirus-2019.

Kermack, W. O. and McKendrick A G. A. (1927). Contribution to the mathematical theory of epidemics. Proceedings of the Royal Society of London A: Mathematical, Physical and Engineering Sciences. The Royal Society, (ss, 700-721)

Kermack, W. O. and McKendrick, A. G. (1932). Contributions to the mathematical theory of epidemics, II-the problem of endemicity. Proceedings of the Royal Society of London A: Mathematical, Physical and Engineering Sciences. The Royal Society, 138, (5), 5-83.

Kraemer, M. U., Yang, C. H., Gutierrez, B., Wu, C. H., Klein, B., Pigott, D. M. and Brownstein, J. S. (2020). The effect of human mobility and control measures on the COVID-19 epidemic in China. Science, 368 (6490), 493-497.

Ndiaye B., Tendeng, L. and Seck, D. (2020). Analysis of the COVID-19 pandemic by SIR model and machine learning technics for forecasting. arXiv.org > q-bio > arXiv:2004.01574v1

Nesteruk, I. (2020). Estimations of the coronavirus epidemic dynamics in South Korea with the use of SIR model. https://doi.org/10.13140/RG.2.2.15489.40807

Pulla, P. (2020). COVID-19: India imposes lockdown for 21 days and cases rise. https://doi.org/10.1136/bmj.m1251. 
Ranjan, R. (2020). Predictions for COVID-19 outbreak in India using Epidemiological models. medRxiv. https://doi.org/10.1101/2020.04.02.20051466.

Türkiye Cumhuriyeti Sağlık Bakanlığı, Koronovirüs (COVID 19) salginı https://covid19bilgi.saglik.gov.tr/tr/haberler/turk iye-deki-gunluk-COVID-19-vaka-sayilari.html

Vyasarayani, C.P. and Chatterjee, A. (2020). Complete dimensional collapse in the continuum limit of a delayed SEIQR network model with separable distributed infectivity. Nonlinear Dynamics 101, 1653-1665. https://doi.org/10.1007/s11071-020$05785-2$

WHO (2020). Naming the coronavirus disease (COVID19) and the virus that causes it, https://www.who.int/emergencies/diseases/nove 1-coronavirus-2019/technical-guidance.

Wikipedia, Türkiye'de COVID-19 pandemisi, https://tr.wikipedia.org/wiki/T\%C3\%BCrkiye\% 27de_COVID-

19_pandemisi_zaman_\%C3\%A7izelgesi

Wu, J. T., Leung, K., and Leung, G. M. (2020). Nowcasting and forecasting the potential domestic and international spread of the 2019nCoV outbreak originating in Wuhan, China: a modelling study. The Lancet, 395 (10225), 689697. 